\title{
Perspektif Generasi Muda Suku Karo Terhadap Kain Tradisional Suku Karo: Sebuah Analisis
}

\author{
Wesnina \\ Program Studi Pendididkan Tata Busana, Fakultas Teknik, Universitas Negeri Jakarta
}

\section{Keywords:}

Knowledge;

Young Karo tribe;

Karo Traditional Cloth

\section{Kata kunci:}

Pengetahuan;

Generasi Muda suku Karo; Kain Tradisional Karo

\section{ABSTRACT}

Abstract: This study aims to find out how the knowledge or perspective of the younger generation of Karo tribe towards Karo tribe traditional cloth. Knowledge on the fabric (cloth) is includes the understanding on Karo traditional cloth, the name and meaning of Karo uis motifs, Karo traditional fabric and its characteristics, and the use of Karo traditional cloth in various cultural activities of Karo tribe. By using a descriptive qualitative method through a survey to the Karo younger generation whose both parents are from Karo tribes, this study found that generally the knowledge of young Karo tribe about traditional cloth. It can be concluded that the Karo young generation still have good and positive attention and the spirit in preserving the cultural and heritage of indigenous Karo tribe.

Abstrak: Penelitian ini bertujuan untuk mengetahui bagaimana pengetahuan atau perspektif generasi muda suku Karo terhadap kain tradisional suku Karo. Pengetahuan tentang kain yang dimaksud meliputi pengertian kain tradisional suku Karo, nama dan makna motif pada uis Karo, macam-macam kain tradisional Karo dan ciri-cirinya, serta kegunaan kain tradisional Karo dalam berbagai kegiatan kebudayaan suku Karo. Dengan menggunakan metode kualitatif deskriptif melalui survey kepada generasi muda suku Karo. Penelitian ini menemukan bahwa pengetahuan generasi muda suku Karo tentang kain tradisionalnya, dan masih memiliki perhatian dan semangat yang cukup positif dalam menjaga kelestarian budaya dan peninggalan adat suku Karo.

Alamat Korespondensi:

Email: wesnina@unj.ac.id (Wesnina)

\section{Pendahuluan}

Karo adalah salah suku bangsa yang mendiami Dataran Tinggi Karo, Sumatera Utara, Indonesia.Nama suku ini dijadikan salah satu nama kabupaten di salah satu wilayah yang mereka diami dataran tinggi Karo yaitu Tanah Karo. Suku ini memiliki bahasa sendiri yang disebut Bahasa Karo atau Cakap Karo. (Tim Tanah Karo Simalem, 2011:17).Masyarakat Karo adalah satu dari beberapa etnis yang terdapat di provinsi Sumatera Utara.Masyarakat Karo yang tinggal di dataran tinggi Tanah Karo, yang sekarang menjadi wilayah administratif Kabupaten Karo sering disebut sebagai Karo Gugung (Sitepu, 1996:5). Menurut Ginting (2009: 8), masyarakat Karo adalah sekelompok manusia yang memiliki kesamaan tertentu dan mengaku dirinya sebagai orang Karo. 
Secara kesejarahan dalam versi Karo, asal muasal suku Karo, kebudayaan, bahasa dan adat istiadat serta perjuangan hidupnya biasanya dinamakan "Turi-turiin atau Terombo Karo". Pada pokok hikayat diuraikan bahwa nenek moyang itu datang dari pesisir Indonesia umumnya, dan Sumatra khususnya yang menurut logat mereka "reh kupertibi si la ertepi enda" dari dua "negeri nini pemena" yaitu leluhur Pemula (Bangun, 2006:26). Berbagai pengarang atau penulis menjelaskan bahwa suku Batak terdiri dari sub suku yaitu : Toba, Karo, Simalungun, Pakpak, Angkola Mandaeling dan Nias. Begitu juga dengan bahasa para pengarang buku telah membukukan bahwa bahasa Batak terdiri dari logat-logat tersebut, namun Karo bukan bagian dari Batak. (Bangun, 2006:129).

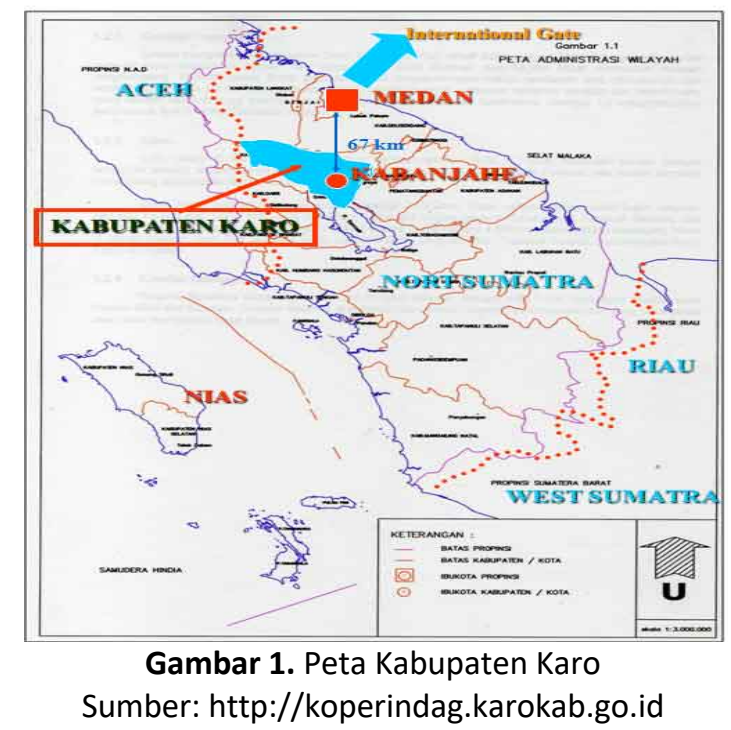

Sebuah konteks dalam sifat manusia tidak terlepas dari aspek psikologis (kejiwaan) manusia itu sendiri.Manusia karo juga tidak terlepas daari keberagaman sifat, sifat yang dimiliki suku Karo tentu berbedabeda tetapi ada sifat dasar pembawaan dari marga yang diapakainya. Marga Karo-karo identik dengan sifat dan karakter berkemauan kuat dan bekerja keras untuk meraih cita-citanya, rata-rata cerdas dalam berfikir dan bertindak.Marga Ginting misalnya, mempunyai jiwa kepemimpianan yang kuat, memiliki keberanian dan karakter kuat dan pintar mengungkapkan pendapat. Marga Sembiring berjiwa diplomatis, marga Tarigan pintar berbicara dan memiliki jiwa pedagang, marga Perangin-angin memiliki karakter pembicara yang baik yang mampu menghibur orang lain, berani bertindak dan mengungkapkan pendapatnya.

Kain atau tekstil tradisional merupakan benda-benda budaya yang patut digali dan dilestarikan, karena ianya merupakan benda bersejarah mengandung makna-makna dan simbol mengenai alam, manusia, dan kepercayaan. Kondisi kain atau tekstil tersebut pada masa atau era milenial ini nyaris diambang kepunaan dikarenakan manusia sekarang asik dengan kepraktisan, instan, dan digital-digitalnya. Era ini menjadikan anak manusia cenderung tidak melihat kebelakang, seperti mereka kurang berminat terhadap pengetahuan yang berbau kebudayaan.

Produksi tekstil atau kain tradisional yang rumit dan memakan waktu yang cukup lama sehingga produksinya juga terbatas, merupakan salam satu alasan generasi muda kurang berminat untuk mencari tau lebih dalam akan hal itu. Generasi muda saat ini disebut juga masyarakat modern, mereka penggunaan kain atau tekstil tradisional dalam kehidupan sehari-hari hampir tidak digunakan lagi, sehingga penggunaan tekstil tradisional ini terbatas pada acara-acara formal kebudayaan saja, sehingga minat generasi muda terhadap tekstil tradisional menjadi rendah.

Dengan latar belakang tersebut maka urgensi untuk kembali melestarikan dan mengenalkan motif tradisional di masyakarat Karo khususnya generasi muda Suku Karo terhadap kain tradisionalnya. Sehingga generasi muda Suku Karo mempunyai peran untuk melestarikan dan mengenalkan benda-benda budaya nya dimasa akan datang.Di sisi lain, Indonesia memiliki banyak sekali jenis kain tradisional yang patut dikenalkan dan dilestarikan melaui generasi muda didaerahnya masing-masing.Penelitian ini diharapkan dapat memperkaya pengetahuan tentang kain tradisional suku Karo berkenaan dengan perspektif generasi muda suku Karo terhadap kain tradisionalnya (benda-benda budaya suku Karo) 


\section{Metode}

Metode penelitian pada dasarnya merupakan cara ilmiah untuk mendapatkan data dengan tujuan dan kegunaan tertentu (Sugiyono, 2011:2). Metode penelitian yang digunakan pada penelitian ini adalah metode deskriptif dengan teknik survei pendekatan kuantitatif.Penelitian deskriptif adalah jenis penelitian yang memberikan gambaran atau uraian atas suatu keadaan sejelas mungkin tanpa ada perlakuan terhadap objek yang diteliti. (Kountur, 2018).

Secara operasional penelitian ini bertujuan untuk mengetahui sejauh mana pengetahuan kaum muda karo tentang kain tradisional Karo, berdasarkan 4 indikator, yaitu: pengetahuan kaum muda mengenai pengertian kain tradisional Karo, pengetahuan kaum muda tentang nama dan makna yang terdapat pada kain tradisional Karo, macam-macam jenis kain tradisional karo, dan penggunaan kain tradisional Karo dalam upacara dan tadisi suku Karo. Penelitian ini dilakukan di daerah Cikarang yang merupakan daerah dimana komunitas suku Karo banyak bertempat tinggal guna memperoleh sampel yang tepat dari populasi yang diinginkan.Sebagai bagian dari sebuah penelitian Survei dilakukan dengan mengambil sampel dari satu populasi dan menggunakan kuesioner sebagai alat pengumpul data yang pokok.(Sugiyono, 2011:6).Dalam penelitian ini menggunakan tes.Metode survei ini digunakan untuk mendapatkan data dari tempat tertentu yang alamiah (bukan buatan), tetapi peneliti melakukan perlakuan dalam pengumpulan data, misalnya dengan mengedarkan kuesioner, test, wawancara terstruktur dan sebagainya (Sugiyono, 2011:6)

Data diperoleh berdasarkan tes yang telah didistribusikan kepada 100 responden kaum muda suku Karo yang berusia 16-30 tahun di Cikarang, sesuai dengan karakteristik yang telah ditentukan yaitu kaum muda atau pemuda-pemudi suku Karo yang kedua orang tua asli suku Karo.

\section{Hasil dan Pembahasan}

\section{Kain Tradisional Karo}

Kain tradisional karo tentunya merupakan salah satu hasil dari kebudayaan Karo, oleh karena itu seiring berkembangnya kebudayaan masyarakat Karo telah memiliki banyak ragam kain dengan fungsi-fungsi yang berbeda.Secara tradisional kain atau uis ini ditenun oleh wanita dengan menggunakan kembaya semacam kapas yang dijadikan benang dan dicelup dengan alat pewarna yang dibuat dari bahan kapur, abu dapur, kunyit, dan telep sejenis tumbuhan. Sebelum ditenun, helai-helai benang dibungkus (diikat) dengan tali plastik sesuai dengan corak atau pola hias yang diingini. Ketika dicelup, bagian benang yang diikat dengan tali plastik tidak akan terwarnai. Tenun ikat ganda dibuat dari menenun benang pakan dan benang lungsin yang keduanya sudah diberi motif melalui teknik pengikatan sebelum dicelup ke dalam pewarna.

Ada tiga jenis tenun ikat yaitu tenun ikat lungsi dimana bentuk ragam hias ikat pada kain tenunnya terdapat pada bagian benang lungsinnya.Tenun ikat pakan dimana bentuk ragam hias ikat pada kain tenun terdapat pada benang bagian pakannya. Tenun ikat berganda atau dobel ikat yaitu bentuk ragam hias pada kain tenun dihasilkan dengan cara mengikat kedua-duanya baik pada bagian benang pakannya maupun lungsin (Kartiwa,1987).

Teknik tenun ikat terdapat di berbagai daerah di Indonesia. Daerah-daerah di Indonesia yang terkenal dengan kain ikat di antaranya: Toraja, Sintang, Jepara, Bali, Lombok, Sumbawa, Sumba, Flores, dan Timor. Kain gringsing dari Tenganan, Karangasem, Bali adalah satu-satunya kain di Indonesia yang dibuat dari teknik tenun ikat ganda dobel ikat. (Katiwa,1987:8).

Kain ikat dapat dibedakan dari kain songket berdasarkan jenis benang.Songket umumnya memakai benang emas atau perak.Motif kain songket hanya terlihat pada salah satu sisi kain, sedangkan motif kain ikat terlihat pada kedua sisi kain.DiSumatra utara ada dua daerah yang menghasilkan kain tenun, yaitu budaya songket Batubara dan ulos dalam budaya Batak atau uis dalam sebutan Karo. Dalam realitasnya kedua budaya ini juga saling mempengaruhi bentuk dan gaya tenun songket.

Ciri khas budaya songket dan ulos di Sumatera Utara, adalah menggunakan tiga jenis alat tenunan, yang pertama adlah okik yang digunakan dalam tradisi songket melayu Batubara, alat tenun 
kedua adalah partonunan, yaitu alat tenun yang digunakan oleh masyarakat Batak Toba untuk menghasilkan ulos. Bedanya dengan okik alat tenun ini dilakukan sambil duduk selepoh, hampir sama dengan okik misalnya dari segi istilah pada okik ada istilah balero dalam partonunan ada balera alat tenun ini digunakan untuk menenun ulos dikawasan Batak Toba dan dipandang alat tenun tradisional Batak Toba. Yang ketiga adalah Alat Tenun Bukan Mesin (ATBM) yaitu alat tenun yang digunakan suku Karo dikawasan budaya Karo dan Dairi tepatnya di Kota Kabanjahe.Ini tidak terlapas dari peranan Bapak S.Tambun, S.Teks. (Djafar, 2010)

Suku Karo menggunakan Alat Tenun Bukan Mesin alasannya adalah bahan tenun yang dihasilkan lebih lebih berkualitas, dan akurasi tenunan lebih baik dibanding dengan menggunakan alat tenun tradisional, okik atau partonunan.Dibawah merupakan gambar ketiga alat tenun yang digunakan di Sumatera Utara (Djafar, 2010 ).

Kain tradisional suku Karo ini sangat penting bagi massyarakat Karo, karna dalam setiap acara adat kebudayaan karo, ataupun kegiatan memasuki rumah dan arisan suku karo mereka juga harus mengenakan kain tradisional ini.Dalam melayat orang karo yang telah meninggal juga sebagai wanita Karo, kaum wanita harus mengenakan kain uis karo yang diselempangkan pada bahu.

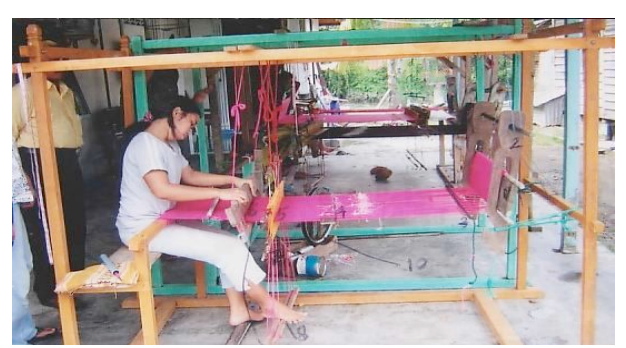

Gambar 2. Okik, Alat Tenun Songket

Sumber: Songket Melayu Batubara; Eksistensi dan Fungsi Sosio-budaya

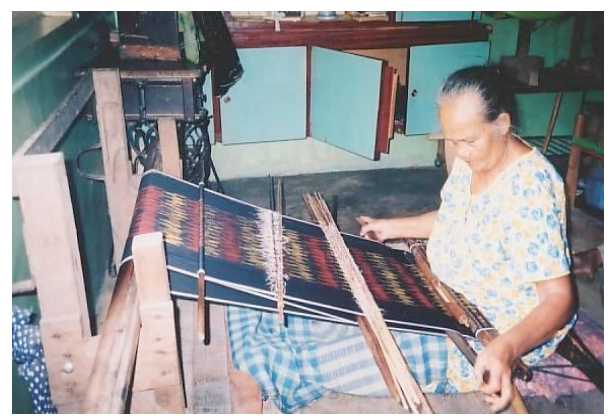

Gambar 3.Partonunan, alat tenun ulos Batak.

Sumber :Songket Melayu Batubara; Eksistensi dan Fungsi Sosio-budaya

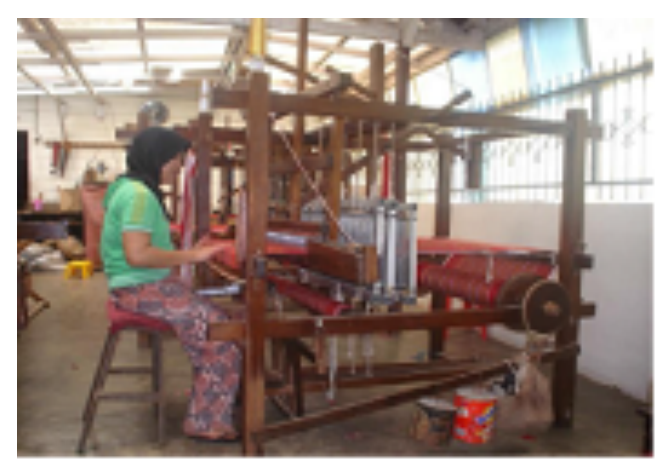

Gambar 4. Gambar Alat Tenun Bukan Mesin.

Sumber: Songket Melayu Batubara; Eksistensi Dan Fungsi Sosio-budaya 
Kain tradisional Karo (Uis Adat Karo) merupakan pakaian adat yang digunakan dalam kegiatan budaya suku karo maupun dalam kehidupan sehari-hari.Uis Karo memiliki warna dan motif yang berhubungan dengan penggunaannya atau dengan pelaksanaan kegiatan budaya.Pada dasarnya Uis Adat Karo dibuat dari bahan kapas, dipintal dan ditenun secara manual dan menggunakan zat pewarna alami (tidak menggunakan bahan kimia pabrikan).Namun ada juga beberapa diantaranya menggunakan bahan kain pabrikan yang dicelup (diwarnai) dengan pewarna alami dan dijadikan kain adat Karo.Dari dahulu motif dari tenun karo ini masi sama dengan yang sekarang digunakan masyarakat karo. Perkembangan zaman belum mempengaruhi motif maupun cara pembuatan kain tradisional ini, namun pengerajin kain tradisional karo semakin berkurang.

Secara umum pakaian tradisional Karo dapat dibagi atas tiga kelompok yaitu pakaian seharihari, pakaian untuk pesta, dan pakaian kebesaran. Pakaian sehari-hari hampir sama dengan pakaian pesta hanya saja lebih rapi, sedangkan pakaian kebesaran terdiri dari pakaian dengan aksesorisaksesoris yang lengkap. Pakaian yang biasa digunakan untuk pria memakai tutup kepala yag disebut tengkuluk atau bulang dan sarung, untuk wanita baju kebaya, sarung atau abit, tutup kepala atau Tudung, dan kain adat Uis Gara yang diselempangkan. Beberapa penggunaan Uis karo dalam kegiatan kebudayaan dan upacara budaya suku karo diantaranya yakni :

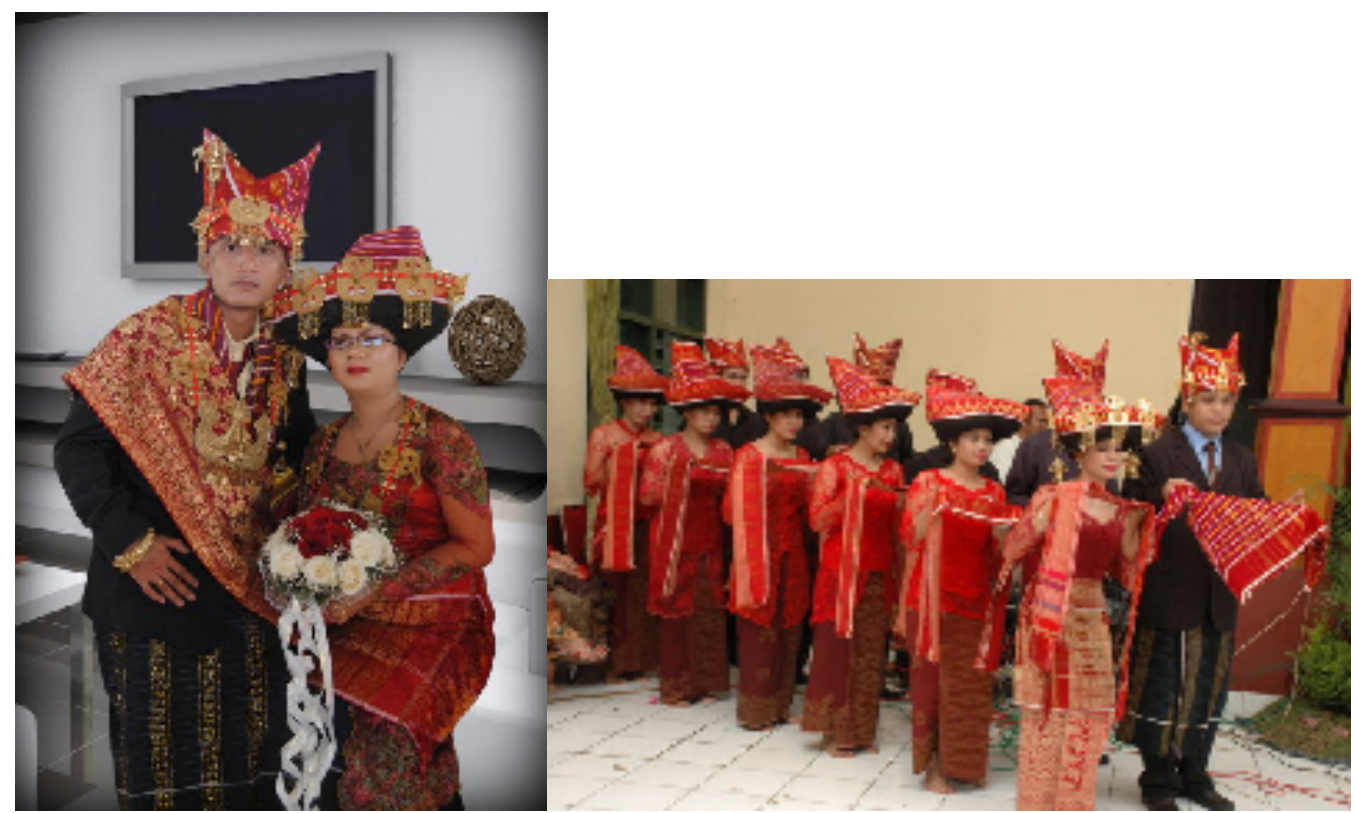

Gambar 5. Penggunaan uis untuk pengantin dan tarian kebudayaan Karo

Sumber : Dokumen Penulis

Kain tradisional uis Karo merupakan simbol keadaan yang sejak dahulu kala dibuat oleh leluhur Karo dan disepakati untuk terus menerus digunakan untuk acara-acara adat tradisional masyarakat karo.Salah satu jenis kain uis Karo yang digunakan sebagai simbol keadatan adalah kain uis gara atau yang sering disebut kai uis nipes.Kain ini merupakan kain yang paling dekat dengan keseharian wanita Karo.Melebihi nilai-nilai adat dan estetika yang terdapat dalam setiap helaian kain tenun tradisional yang ada di Indonesia maupun daerah Karo, kain uis gara atau nipes ini mengandung makna yang sangat mendalam bagi wanita-wanita Karo.

Uis gara merupakan representasi dari kasih sayang semesta alam yang yang diumpamakan sebagai ibu manusia yang disalurkan melalui sehelai benang yang ditenun dengan kehangatan kasih sayang seorang ibu menjadi selembar kaim uis yang merupakan pelambang kasih sasih sayang orang tua terhadap ana.Dimasa lampau, perempuan-perempuan karo sangat bangga menenun sendiri kain uis, memakai dan mewariskannya kepada keluarga sebagai suatu pusaka yang diwariskan secara 
turun-temurun, uis ini berwarna merah hati dan motif yang digunakan bunga gundur.Bagi wanita masa kini, uis nipes adalah pelengkap untuk acara adat yang tidak boleh dilupakan karena uis nipes merupakan identitas seorang wanita Karo saat acara adat. Selebihnya uis nipis hanya disimpan di lemari atau terkadang dijadikan penghias ruangan, sebagai taplak meja tamu atau hiasan dinding.

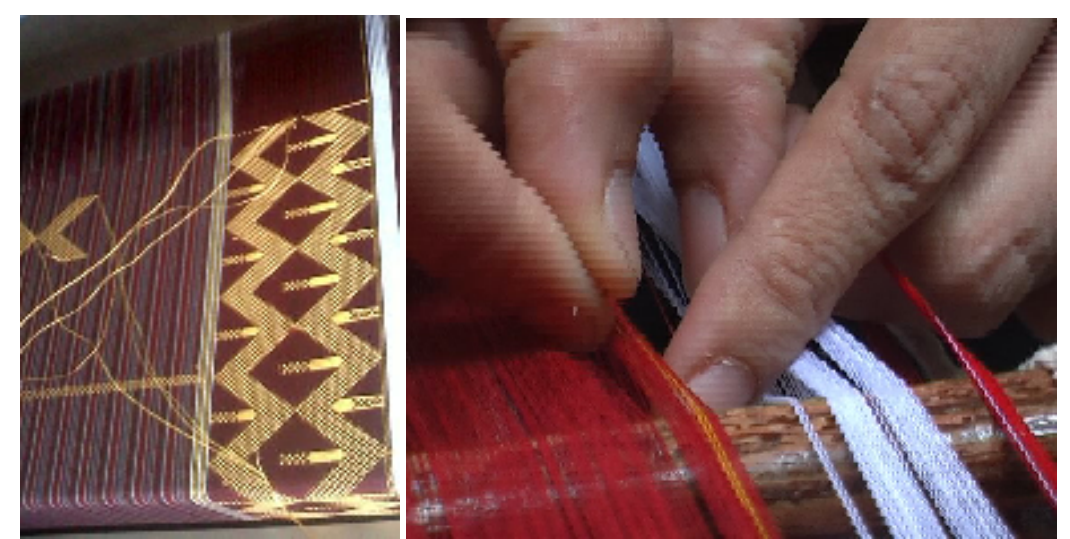

Gambar 6. Pembuatan kain tradisional Karo uis nipes dan Pembuatan Uis Karo Sumber : Dokumen Penulis

Beberapa diantara Uis Adat Karo tersebut sudah langka karena tidak lagi digunakan dalam kehidupan sehari-hari, atau hanya digunakan dalam kegiatan ritual budaya yang berhubungan dengan kepercayaan animisme dan saat ini tidak dilakukan lagi.

\section{Hasil Survey}

Berdasarkan analisis data survey pengetahuan generasi muda suku karo terhadap kain tradisional suku yang diukur melalui 4 indikator, yaitu :Pengertian Terhadap Kain Tradisional Karo, Nama Dan Makna Motif Dalam Tenun Tradisional Karo, Macam-Macam Jenis Kain Tradisional Karo, dan Penggunaan Kain Tradisional Karo Dalam Kegiatan Kebudayaan.

Persentase pengetahuan responden tentang pengertian kain tradisional Karo dari 7 pertanyaan sebagai berikut :

Tabel 1. Persentase Pengertian Kain Tradisional Karo

\begin{tabular}{lll}
\hline Aspek yang dinilai & Persentase & Keterangan \\
\hline Pengetahuan tentang pengertian kain & $26,86 \%$ & Salah \\
tradisional Karo & $73,14 \%$ & Benar \\
\hline Total & $100 \%$ & \\
\hline
\end{tabular}

Berdasarkan hasil penelitian tersebut, maka dapat disimpulkan bahwa kaum muda suku Karo yang berada di Cikarang yang merupakan suku Karo dan kedua orang tuanya asli suku Karo memiliki pengetahuan $(73,14 \%)$ mengenai pengertian dari kain tradisional Karo. Ini berarti bahwa kaum muda suku Karo cukup mengetahui tentang pengertian kain tradisional Karo.Responden cukup mengetahui pengetian kain tradisional Karo.

Hasil jawaban responden mengenai “Nama Dan Makna Motif Dalam Tenun Tradisional Karo" ditampilkan sebagai berikut: 
Tabel 2. Persentase Nama dan makna motif yang terdapat pada Kain tradisional Karo

\begin{tabular}{lllll}
\hline Aspek yang dinilai & & Persentase & Keterangan \\
Nama dan makna motif yang terdapat pada kain $21,4 \%$ & Salah \\
tradisional Karo & & $78,6 \%$ & Benar \\
\hline Total & $100 \%$ & \\
\hline
\end{tabular}

Berdasarkan hasil jawaban tersebut, maka dapat disimpulkan bahwa kaum muda suku Karo yang berada di Cikarang yang merupakan suku Karo dan kedua orang tuanya asli suku Karo memiliki pengetahuan $(78,6 \%)$ mengenai nama motif dan makna motif yang ada dalam kain tradisional Karo. dan sebanyak 21,4\% tidak mengetahui. Ini berarti kaum muda suku Karo memiliki pengetahuan yang baik mengenai nama motif dan makna motif pada uis Karo. Responden mengetahui dengan baik mengenai nama moti dan makna moyif yang ada pada kain tradisional Karo.

Indikator ketiga adalah "Macam-Macam Jenis Kain Tradisional Karo". Persentase pengetahuan responden tentang macam-macam jenis kain tradisional Karo dari 7 pertanyaan sebagai berikut :

Tabel 3. Persentase Pengetahuan mengenai Macam-macam jenis kain tradisional Karo dalam kegiatan kebudayaan

\begin{tabular}{|c|c|c|}
\hline Aspek yang dinilai & Persentase & Keterangan \\
\hline \multirow{2}{*}{$\begin{array}{l}\text { Pengetahuan mengenai kegunaan kain tradisional Karo dalam } \\
\text { kegiatan kebudayaan }\end{array}$} & $28 \%$ & Salah \\
\hline & $72 \%$ & Benar \\
\hline Total & $100 \%$ & \\
\hline
\end{tabular}

Berdasarkan hasil penelitian tersebut, maka dapat disimpulkan kaum muda suku Karo yang berada dicikarang dan kedua orang tua asli suku Karo memiliki pengetahuan $72 \%$ tentang macammacam jenis kain tradisional Karo.Responden yang tidak mengetahui macam-macam jenis kain tradisional Karo $28 \%$.ini berarti kaum muda suku Karo memiliki pengetahuan yang cukup mengenai macam-macam jenis kain tradisional Karo.Responden dalam penelitian ini memiliki pengetahuan yang cukup mengenai macam-macam kain tradisional Karo. Indikator ketiga adalah "Penggunaan Kain Tradisional Karo Dalam Kegiatan Kebudayaan". Jawaban responden ditampilkan pada Tabel berikut ini:

Tabel 4. Persentase Pengetahuan mengenai kegunaan kain tradisional Karo dalam kegiatan kebudayaan

\begin{tabular}{lll}
\hline Aspek yang dinilai & Persentase & Keterangan \\
\hline Pengetahuan mengenai kegunaan kain tradisional Karo & $45 \%$ & Salah \\
dalam kegiatan kebudayaan & $54 \%$ & Benar \\
\hline Total & $100 \%$ & \\
\hline
\end{tabular}

Berdasarkan hasil penelitian tersebut, maka dapat disimpulkan bahwa kaum muda suku Karo yang bertempat tinggal di Cikarang yang kedua orang tua asli suku Karo memiliki pengetahuan tentang penggunaan kain tradisional Karo dalam kebudayaannya $54 \%$, dan $45 \%$ kaum muda suku 
Karo di Cikarang tidak mengetahui tentang penggunaan kain tradisional Karo dalam kegiatan kebudayaan dan upacara adat secara detail. Ini berarti kaum muda suku Karo memiliki pengetahuan yang kurang baik mengenai penggunaan kain tradisional Karo dalam kegiatan kebudayaan Karo.Responden dalam penelitian ini memilikipengetahuan yang kurang baik mengenai penggunaan kain tradisional Karo. Indikator ke-empat adalah Pengetahuan kaum muda suku Karo tentang kain tradisional suku Karo. Melalui hasil survei ditemukan fakta dilapangan sebagai berikut:

Tabel 5. Persentase Pengetahuan kaum muda suku Karo tentang kain tradisional suku Karo

\begin{tabular}{llllll}
\hline Aspek yang dinilai & & & Persentase & Keterangan \\
\hline Pengetahuan kaum muda & suku & Karo tentang kain & $30,44 \%$ & Salah \\
tradisional suku Karo & & & $69,56 \%$ & Benar \\
\hline Total & & $100 \%$ \\
\hline
\end{tabular}

Berdasarkan hasil penelitian tersebut, maka dapat disimpulkan bahwa pengetahuan kaum muda suku Karo yang berada di Cikarang yang kedua orang tua asli suku Karo memiliki pengetahuan mengenai kain tradisional Karo 69,56\%, dan 30,44\% kaum Muda suku Karo yang ada di Cikarang tidak memiliki pengetahuan tentang kain tradisional sukunya. Ini berarti kaum muda suku Karo memiliki pengetahuan yang cukup baik mengenai kain tradisional Karo. Responden cukup mengetahui kain tradisional Karo, hal ini menunjukkan bahwa kaum muda suku Karo yang berada di Cikarang memiliki pengetahuan yang cukup baik tentang kain tradisional Karo dimana kain ini merupakan kain khas budaya Karo dan memiliki perananan yang penting dalam upacara kebudayaan Karo serta memiliki makna yang mendalam bagi masyarakat Karo dan merupakan warisan budaya bangsa. Disamping itu juga Cikarang merupakan kota yang mudah dalam mendapatkan infomasi dan memiliki masyarakat Karo yang masi berasal dari Tanah Karo, Sumatra Utara.

Dari keempat indikator yang digunakan sebagai standar dalam penelitian, Pengetahuan tentang nama motif dan makna motif pada uis Karo memiliki persentasi yang lebih tinggi, hal ini dimungkinkan karena responden sering melihat kain tradisional Karo dipakai oleh orang tua dalam kegiatan-kegiatan kebudayaan, dan sebagian besar responden juga masih mendapatkan pendidikan kebudayaan Karo saat bersekolah ditanah Karo.

Maka beradasarkan Arikunto (2010: 387) yang menyatakan bahwa "apabila peneliti sudah menentukan standar bahwa "> 75\% baik, antara 60-75\% cukup, < dari 60\% kurang baik". Maka data yang diperoleh sebesar 69,56\% menunjukkan bahwa kaum muda suku Karo di Cikarang boleh dikatakan cukup memiliki pengetahuan tentang adat istiadat ataupun dalam hal ini secara khusus adalah kain ikat tradisional suku Karo.

\section{Simpulan}

Berdasarkan hasil penelitian yang telah dilakukan oleh peneliti bahwa sebagai kaum muda suku Karo yang bertempat tinggal di Cikarang memiliki pengetahuan yang cukup memadai tentang kain tenun tradisional suku Karo. Hal ini dapat diketahui dari hasil penyebaran angket berupa tes kepada 100 orang responden didapati bahwa sebesar $69,56 \%$ responden memiliki pengetahuan atau pemahaman, sedangkan 30,44 \% persen lainnya tidak mengetahui tentang tenun kain tradisional suku Karo. Seiring berkembangnya zaman, informasi tentang uis Karo dapat diperoleh responden melalui internet sehingga mempengaruhi pengetahuan kaum muda suku Karo yang yang tinggal di Cikarang.

Pengetahuan sebagian besar kaum muda Karo yang berada di Cikarang tentang pengertian kain tradisional Karo adalah $73,14 \%$, nama motif dan makna motif pada uis Karo adalah $78,6 \%$, 
tentang macam-macam kain tradisional Karo dan ciri-cirinya adalah $72 \%$, dan kegunaan kain tradisional Karo dalam kegiatan kebudayaan Karo memiliki pengetahuan 55\%.

Berdasarkan kesimpulan yang telah dikemukakan sebelumnya, maka implikasi yang diperoleh berdasarkan hasil penelitian adalah : (1) Dengan adanya penelitian pengetahuan kaum muda suku Karo, maka kaum muda belajar lebih mengenal kain tradisional sukunya; (2) Menambah pengetahuan yang lebih baik untuk kaum muda suku Karo dan mahasiswi busana akan kain tradisional Karo, sehingga nantinya mahasiswi dapat menciptakan busana-busana yang bernilai seni dan menjadikan kain tradisional karo smakin dikenal orang banyak dan tetap terjaga kelestariannya; (3) Menumbuhkan jiwa cinta budaya dan kekayaan seni budayanya khususnya kain tradisional Karo; (4) Hasil penelitian ini dapat digunakan oleh mahasiswa busana dan massyarakat umumnya untuk menambah pengetahuan; dan (5) Sebagai salah satu referensi bagi Universitas Negeri Jakarta dalam penelitian selanjutnya mengenai kain tradisional Karo.

\section{Daftar Pustaka}

Arikunto, S. 2010, Prosedur Penelitian Suatu Pendekatan Praktek. Jakarta: Rineka Cipta.

Bangun, R. 2006, Mengenal Suku Karo. Jakarta: PT. Kesaint Blane Indah.

Djafar, F.M. 2010. Songket Melayu batu Bara eksistensi dan sosial Budaya. Medan: USU.

Ginting, F. 2009. Pendapat Massyarakat Karo terhadap Gaun Pengantin Barat Modifikasi Uis Bekah Buluh. Jakarta: Perpus UNJ

Katiwa, S. 1978, Tenunlkat / Indonesia Ikats. Jakarta: Djambatan.

Katiwa, S. 1998, Tenun Ikat. Jakarta: Djambatan

Kountur, R. (2018). Metode penelitian untuk penulisan skripsi dan tesis. Jakarta: PPM.

Sitepu, Sempa. 1996. Pilar Budaya Karo. Medan: Bali.

Sugiyono, 2011, Metode Pendidikan Penelitian (Pendekatan Kuantitatif Kualitatif dan R\&D). Bandung: Alfabeta.

Tim Tanah Karo Simalem, 2011, Mengenal Kabupaten Karo. Medan: CV. Mitra. 